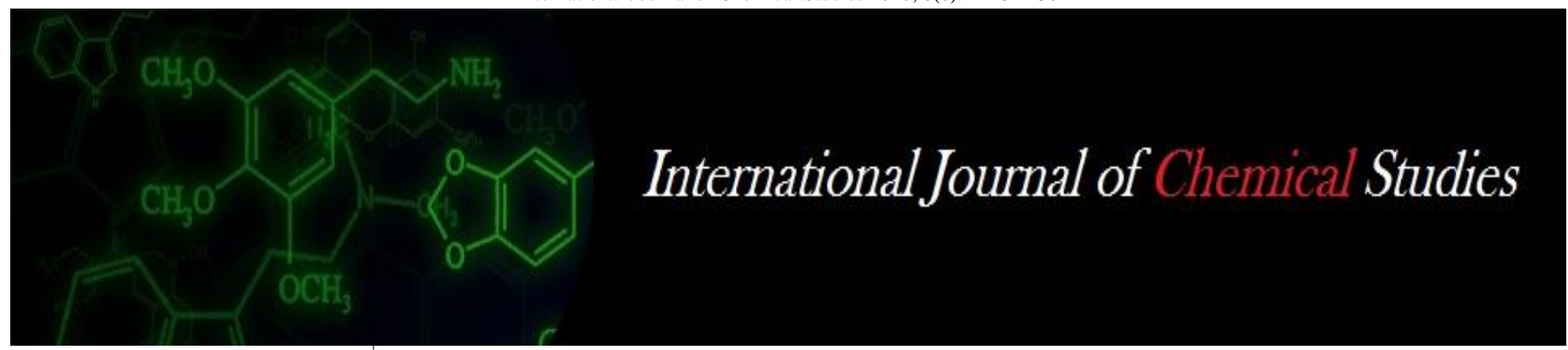

P-ISSN: 2349-8528

E-ISSN: 2321-4902

www.chemijournal.com

IJCS 2020; 8(6): 2228-2230

(C) 2020 IJCS

Received: 15-09-2020

Accepted: 17-10-2020

Godavari S Gaikwad

Assistant Professor, Department

of Agronomy, Dr. PDKV, Akola,

Maharashtra, India

\section{Dr. AN Paslawar}

Professor, Department of

Agronomy, Dr. PDKV, Akola,

Maharashtra, India

Dr. ND Parlawar

Professor and Head, Department of Agronomy, Dr. PDKV, Akola,

Maharashtra, India

\section{SM Sawadhkar}

Assistant Professor, Department of Agronomy, Dr. PDKV, Akola, Maharashtra, India
Corresponding Author: Godavari S Gaikwad

Assistant Professor, Department of Agronomy, Dr. PDKV, Akola, Maharashtra, India

\section{Physical, chemical and biological properties of soil as influenced by organic sources in cotton under rainfed condition}

\author{
Godavari S Gaikwad, AN Paslawar, ND Parlawar and SM Sawadhkar
}

DOI: $\underline{\text { https://doi.org/10.22271/chemi.2020.v8.i6af.11105 }}$

\begin{abstract}
The field experiment was conducted during 2017-18 to study the Physical, chemical and biological properties of soil as influenced by organic sources in cotton under rainfed condition at Cotton Research Unit, Dr. Panjabrao Deshmukh Krishi Vidyapeeth, Akola during kharif season. The physical, chemical and biological properties were improved with FYM @ $12.5 \mathrm{t} \mathrm{ha}^{-1}$ followed by seed treatment of biofertilzer + PPFM PGR spray @ 1\% + neem cake @ $250 \mathrm{~kg} \mathrm{ha}^{-1}$ with cotton + sunhemp GMS (1:1). Soil available nitrogen, phosphorus and potassium after harvest of crop were influenced significantly due to different organic sources of manures. Significantly more nitrogen, phosphorus and potassium were remained in soil where RD of nutrient applied through organics on P equivalent basis (FYM @ 12.5t ha-1) after second year of study. While minimum soil available nutrients were observed control/no organics. Different organic sources showed numerically higher number microbial population (Bacteria, Fungi and Actinomycetes) was found in FYM and combined application of green manuring and cotton + blackgram and sunhemp intercropping + neem cake application@ @250 $\mathrm{kg} \mathrm{ha}^{-1}$ at $50 \%$ flowering and $50 \%$ boll bursting stage of crop during both the years of study.
\end{abstract}

Keywords: Organic sources, pink pigmented facultative methylobacterium, physico-chemical, biolotical properties

\section{Introduction}

Organic agriculture is developing rapidly and is practiced in 178 countries across the globe with 57.8 million hectares including conversion areas accounting for $1.2 \%$ of the world's agricultural lands. In 2016, India ranked $9^{\text {th }}$ in area with 1.49 million hectares under organic cultivation (Anonymous, 2018) ${ }^{[1]}$. Organic cotton is already successfully being in 18 countries around world. However, the vast majority (84\%) takes place in just in four countries, India (51\%), China (19.0\%), Turkey (7.0\%) and Kyrgyzstan (7.0\%). The total land area of all organic cotton growing internal Control system (ICS) was 359 ha of which it is estimated that $43-45 \%(168,654 \mathrm{ha})$ was actually planted with organic cotton. Organic cotton production is estimated at $60,000 \mathrm{MT}$, sharing $51 \%$ of global organic production which is the highest in the world. Based on current projections, it is estimated that organic cotton production will grow 35-40\% by 2020 . (Anonymous, 2018) ${ }^{[1]}$. Maharashtra is the leading state in respect of area (41.98 lakh hectare) under cotton cultivation, which shares 38.59 per cent of total cotton growing area of the country (12.23 million hectares) but ranks second in production (85 lakh bales) next to Gujarat (104 lakh bales) and $9^{\text {th }}$ in productivity (344 $\left.\mathrm{kg} \mathrm{ha}^{-1}\right)$. Vidarbha region of Maharashtra shares 39.62 per cent area (15.08 lakh hectare) and 44 per cent of total production of Maharashtra with an average productivity of $300 \mathrm{~kg}$ lint $\mathrm{ha}^{-1}$ (Anonymous 2018) ${ }^{[1]}$. Main reason for low productivity in Maharashtra and Vidarbha is maximum area under rainfed condition, lack of organic manure and monocropping over the years.

The organic inputs not only reduce cost but help to build up soil humus and beneficial microbes besides, improving the soil physical properties. Manure is any animal or plant material (neem cake) used to fertilize land especially animal excreta for improving the soil fertility and thus promoting plant growth and also increase the nitrogen and phosphorous content in the soil. Neem cake is a source of organic manure and soil conditioner. Green manuring (In-situ) crops act as field covers which suppresses the weeds through smothering effects and conserve soil moisture by reducing evaporation from the soil and more nutrient supply through in-situ green manuring conservation practices and consequent better formation and translocation of assimilates from source to sink might have increased seed cotton yield under moisture conservation practices. Biofertiliser is one of natural and sustainable nutritional input. Mainly there are two types of biofertilizers which are used on mass scale. These are nitrogenous and phosphatic biofertilizers. These organisms with the help of nitrogenase enzyme fix atmospheric nitrogen (Venkatashwarlu, 2008) ${ }^{[10]}$. 
Pink-pigmented facultative methylotrophs (PPFMs) are Gramnegative bacteria with the ability to use $\mathrm{C}-1$ compounds such as formate, formaldehyde and methanol as sole source of carbon and energy Pink Pigmented Facultative Methylotrophs are organisms are capable of growing on compounds containing one carbon. (Green and Bousifield, 1982). Methylotrophs are known to possess antagonistic activities, which can be used to protect a plants from pathogens and, therefore, to improve the health of plants. The main role of PPFM cytokinin production in plants, and might play a role in plant growth promotion result increasing in yield of cotton. The PPFMs offer the associative symbiotic life with crop plants by utilizing the methanol emitted through the leaves and in turn provide cytokinins to the plants. They are able to produce plant growth regulators such as cytokinins and auxins which affect plant growth and different physiological processes.

\section{Material and Methods}

The field experiment on "Physical, chemical and biological properties of soil as influenced by organic sources in cotton under rainfed condition" was conducted at Cotton Research Unit which was located at Central Research Station, Dr. Panjabrao Deshmukh Krishi Vidyapeeth, Akola, during 2017-18. The experiment was laid out in randomized block design with three replication and ten treatments. The treatments consist of $\mathrm{T}_{1}$ : Absolute control (no organic/ Inorganics), $\mathrm{T}_{2}$ : Recommended dose of nutrient through organics on P equivalent basis (FYM @ 12.5t ha ${ }^{-1}$ ), T3: Seed treatment (ST) of biofertilizer + foliar application of pink pigmented facultative metylobacterium (PPFM) @ $1 \%$ at flowering (FL) \& boll development (BD), $\mathrm{T}_{4}$ : Neem cake (NC) @ $250 \mathrm{kgha}^{-1}, \mathrm{~T}_{5}$ : green manuring of sunhemp (GMS) in between cotton rows (1:1), $\mathrm{T}_{6}$ : Intercrop with blackgram (1:1), $\mathrm{T}_{7}: \mathrm{ST}+\mathrm{PPFM} @ 1 \%$ at FL \& BD+ NC, T8: ST + PPFM @ $1 \%$ at FL \& BD + cotton+ sunhemp (GMS) (1:1), $\mathrm{T}_{9}: \mathrm{ST}+\mathrm{PPFM} @ 1 \%$ at FL \& BD+ NC + cotton + sunhemp (GMS) $(1: 1)$ and $\mathrm{T}_{10}: \mathrm{ST}+\mathrm{PPFM} @ 1 \%$ at FL \& $\mathrm{BD}+\mathrm{NC}+$ intercrop with blackgram (1:1).

The soil of the experimental site was clayey and slightly alkaline in nature $(\mathrm{pH} 8.08)$ having moderate organic carbon content $(3.80 \mathrm{~g} \mathrm{~kg}$ ${ }^{1}$ ), low in available $\mathrm{N}\left(175.6 \mathrm{kgha}^{-1}\right)$, medium in available $\mathrm{P}_{2} \mathrm{O}_{5}$ $\left(15.10 \mathrm{kgha}^{-1}\right)$ and high in available $\mathrm{K}_{2} \mathrm{O}\left(375.4 \mathrm{kgha}^{-1}\right)$.

The bulk density was determined at field capacity by clod coating and porosity of soil mass is the ratio of volume of voids to the total volume of given soil mass (Singh 1980) while Soil hydraulic conductivity was determined by constant head method (Black, 1965). The soil $\mathrm{pH}$ and Electrical conductivity (Glass electrode method using $\mathrm{pH}$ meter and Electrical conductivity bridge (Jackson, 1967), Organic carbon (Walkey and Black method 1934) ${ }^{[11]}$, Available nitrogen was determined by alkaline permanganate method using microprocessor based automatic distillation system (Subbiah and Asija, 1956). Phosphorus (Olsen's Method using 0.5 M sodium bicarbonate as an extractant using UV based double beam spectrophotometer (Olsen and Sommers, 1982). Available potassium was determined by neutral normal ammonium acetate method and Soil microbial population was determined by serial dilution plate technique (Wollum, 1982) ${ }^{[12]}$.

\section{Results and Discussion \\ 1. Physical properties of soil as influenced by different organic sources of manures}

Data relevant to soil physical properties such as properties such as bulk density, porosity and hydraulic conductivity of soil is presented in table 1. Reduction in Bulk density of soil was noticed with the application of recommended dose of FYM @ $12.5 \mathrm{t} \mathrm{ha}^{-1}$, followed by ST+ PPFM @1\% at FL \& BD+ NC + cotton+ sunhemp (GMS) (1:1), ST + PPFM @ $1 \%$ at FL \& BD + cotton+ sunhemp (GMS) (1:1), ST + PPFM @1 \% at FL \& BD+ NC + Intercrop with blackgram BGS (1:1), Intercrop with blackgram BGS (1:1) and GM of sunhemp (GMS) in between cotton rows (1:1). Reduction in bulk density of soil with incorporation of FYM, in-situ green manurung of sunhemp and over control treatment and significant improvement in bulk density in Vertisols with application of FYM alone as a source of nitrogen. The analogus findings were reported by Rao and Janawade (2009) ${ }^{[8]}$.

Whereas, porosity and hydraulic conductivity of soil increased with the application of FYM $12.5 \mathrm{t} \mathrm{ha}^{-1}$ (47.17 per cent) which was followed by the combined application of seed treatment of biofertilizer + PPFM @1\% at FL \& BD+ cotton+ sunhemp (GMS) along with neem cake application @ $250 \mathrm{~kg} \mathrm{ha}^{-1}$. This might be due to better aggregation and increased porosity as a consequence of the addition of organics have a favourable influence on the physical properties such as hydraulic conductivity which influences the soil water dynamics. Similar results quoted by Chalwade et al. (2006) ${ }^{[2]}$.

Table 1: Bulk density $\left(\mathrm{Mg} \mathrm{m}^{-3}\right)$, Porosity $(\%)$ and Hydraulic conductivity $\left(\mathrm{cmhr}^{-1}\right)$ of soil as influenced by different organic sources of manures

\begin{tabular}{|c|c|c|c|c|}
\hline \multicolumn{2}{|r|}{ Treatment } & $\begin{array}{l}\text { Bulk density } \\
\left(\mathrm{Mg} \mathrm{m}^{-3}\right)\end{array}$ & $\begin{array}{l}\text { Porosity } \\
(\%)\end{array}$ & 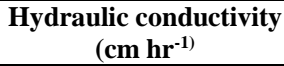 \\
\hline $\mathrm{T}_{1}$ & Absolute control (no organic/ Inorganics) & 1.44 & 45.66 & 0.56 \\
\hline$T_{2}$ & RD of Nutrient through organics on P equivalent basis (FYM @ 12.5t ha ${ }^{-1}$ ) & 1.40 & 47.17 & 0.66 \\
\hline$T_{3}$ & Seed treatment of bio- fertilizer + foliar application of PPFM @ $1 \%$ at FL \& BD & 1.42 & 46.42 & 0.59 \\
\hline $\mathrm{T}_{4}$ & Neem cake (NC)@ 250 kgha-1 & 1.43 & 46.04 & 0.60 \\
\hline$T_{5}$ & GM of sunhemp (GMS) in between cotton rows (1:1) & 1.42 & 46.42 & 0.62 \\
\hline $\mathrm{T}_{6}$ & Intercrop with blackgram BGS $(1: 1)$ & 1.42 & 46.42 & 0.58 \\
\hline $\mathrm{T}_{7}$ & ST + PPFM @ $1 \%$ at FL \& BD+ NC & 1.42 & 46.42 & 0.58 \\
\hline $\mathrm{T}_{8}$ & ST + PPFM @ $1 \%$ at FL \& BD + cotton + sunhemp (GMS) (1:1) & 1.42 & 46.42 & 0.62 \\
\hline $\mathrm{T}_{9}$ & ST+ PPFM @ $1 \%$ at FL \& BD+ NC + cotton+ sunhemp (GMS) (1:1) & 1.42 & 46.42 & 0.63 \\
\hline $\mathrm{T}_{10}$ & ST + PPFM @ $1 \%$ at FL \& BD+ NC + Intercrop with blackgram BGS (1:1) & 1.43 & 46.04 & 0.62 \\
\hline
\end{tabular}

\section{Chemical properties of soil as influenced by different organic sources of manures}

Data relevant to soil chemical properties such as soil reaction $(\mathrm{pH})$, electrical conductivity Organic carbon and available NPK is presented in table 2. Reduction in soil $\mathrm{pH}$, EC was observed in with application of FYM @ $12.5 \mathrm{t} \mathrm{ha}^{-1}$ over no organic treatment (7.89 and $0.26 \mathrm{dSm}^{-1}$, respectively.). The next best treatment or was slightly reduced in ST+ PPFM @ $1 \%$ at FL \& BD+ NC + cotton + sunhemp (GMS). The improvement in the $\mathrm{pH}$ and EC of the soil might be due to application of FYM, seed treatment of biofertilizer, neem cake and intercropping with black gram and sunhemp used as organic nutritional sources for the crop. The results are in agreement with Halemani et al. (2004) ${ }^{[5]}$ and Gupta and Sharma, (2009) ${ }^{[4]}$.

Table 2: Nutrient status of soil at initial and after harvesting of cotton as influenced by different organic sources of manures

\begin{tabular}{|c|c|c|c|c|c|c|c|}
\hline \multirow{2}{*}{\multicolumn{2}{|c|}{ Treatment }} & \multicolumn{6}{|c|}{ Nutrient status of soil } \\
\hline & & $\underset{(1: 2.5)}{\mathbf{p H}}$ & $\begin{array}{c}\mathrm{EC} \\
\left(\mathrm{dSm}^{-1}\right)\end{array}$ & $\begin{array}{l}\text { Organic } \\
\text { carbon } \\
\left(\mathrm{g} \mathrm{kg}^{-1}\right)\end{array}$ & $\begin{array}{c}\mathrm{N} \\
\left(\mathrm{kg} \mathrm{ha}^{-1}\right)\end{array}$ & $\underset{\left(\mathrm{kg} \mathrm{ha}^{-1}\right)}{\mathbf{P}}$ & $\frac{\mathrm{K}}{\left(\mathrm{kg} \mathrm{ha}^{-1}\right)}$ \\
\hline $\mathrm{T}_{1}$ & Absolute control (no organic/ Inorganics) & 8.07 & 0.33 & 3.72 & 173.4 & 14.6 & 373.3 \\
\hline $\mathrm{T}_{2}$ & RD of Nutrient through organics on P equivalent basis (FYM @ 12.5t ha ${ }^{-1}$ ) & 7.89 & 0.26 & 4.80 & 208.6 & 20.1 & 396.1 \\
\hline $\mathrm{T}_{3}$ & Seed treatment of bio- fertilizer + foliar application of PPFM @ $1 \%$ at FL \& BD & 8.08 & 0.34 & 3.86 & 182.7 & 16.3 & 379.4 \\
\hline $\mathrm{T}_{4}$ & Neem cake (NC) @ 250 kgha ${ }^{-1}$ & 8.10 & 0.32 & 4.30 & 189.6 & 18.0 & 385.9 \\
\hline
\end{tabular}




\begin{tabular}{|c|c|c|c|c|c|c|c|}
\hline $\mathrm{T}_{5}$ & GM of sunhemp (GMS) in between cotton rows (1:1) & 8.03 & 0.30 & 4.12 & 193.5 & 18.2 & 385.5 \\
\hline $\mathrm{T}_{6}$ & Intercrop with blackgram BGS (1:1) & 8.05 & 0.31 & 3.98 & 187.5 & 17.4 & 381.7 \\
\hline $\mathrm{T}_{7}$ & ST + PPFM @ 1\% at FL \& BD+ NC & 8.07 & 0.32 & 4.39 & 195.4 & 18.6 & 388.6 \\
\hline $\mathrm{T}_{8}$ & ST + PPFM @1\% at FL \& BD + cotton+ sunhemp (GMS) (1:1) & 8.04 & 0.30 & 4.24 & 198.5 & 19.0 & 392.1 \\
\hline $\mathrm{T}_{9}$ & ST+ PPFM @1\% at FL \& BD+ NC + cotton+ sunhemp (GMS) (1:1) & 8.01 & 0.29 & 4.57 & 202.8 & 19.3 & 394.4 \\
\hline $\mathrm{T}_{10}$ & ST + PPFM @ $1 \%$ at FL \& BD+ NC + Intercrop with blackgram BGS (1:1) & 8.05 & 0.31 & 4.20 & 205.3 & 19.4 & 394.8 \\
\hline & $\mathrm{SE}(\mathrm{m}) \pm$ & - & - & - & 0.25 & 0.15 & 1.10 \\
\hline & $\mathrm{CD}$ at $5 \%$ & - & - & - & 0.77 & 0.44 & 2.15 \\
\hline
\end{tabular}

With regards to organic carbon content of soil, recommended dose of nutrients through FYM, seed treatment of biofertilizer, green manuring, neem cake and intercropping of legumes as source of plant nutrient to cotton showed remarkable improvement over the control. Maximum build up of organic carbon content of soil after harvest of cotton with the addition of recommended dose of well decomposed organic matter i.e. FYM @ $12.5 \mathrm{t} \mathrm{ha}^{-1}$ was observed and it was to the tune of $4.80 \mathrm{~g} \mathrm{~kg}^{-1}$ and lower organic carbon $3.72 \mathrm{~g} \mathrm{~kg}^{-1}$ was observed in absolute control /no organics. Similar results were reported by Ghuman et al. (2006) ${ }^{[3]}$ and Ravindra Kumar et al. (2016) ${ }^{[9]}$.

Maximum amount of available nitrogen, phosphorus and nitrogen (208.60, 20.10 and $396.1 \mathrm{~kg} \mathrm{ha}^{-1}$, respectively), was noticed in the treatment of recommended dose of nutrient was applied through FYM @ $12.5 \mathrm{t} \mathrm{ha}^{-1}$, suggesting the actual gain of $23 \mathrm{~kg} \mathrm{ha}^{-1}$ over initial nitrogen status and proved itself statistically superior over remaining treatments. Increment in available nitrogen with the application of FYM @ $12.5 \mathrm{t} \mathrm{ha}^{-1}$ over absolute control treatment was 16.88 per cent.

The next best treatment was combined application of seed treatment with biofertilizer + PFFM@1\% spray at flowering and boll development stage + neem cake @ $250 \mathrm{~kg} \mathrm{ha}^{-1}+$ intercrop of cotton + blackgram BGS $205.33 \mathrm{~kg} \mathrm{ha}^{-1}$ and followed by seed treatment of biofertilizer + PFFM @ 1\% spray at flowering and boll development stage + neem cake @250 kg ha-1 + cotton + sunhemp GMS. The minimum value of soil available nitrogen was observed with treatment of control/no organics. The increase was due to more exposure of soil particle probably coupled had been the development of predominat fraction in decomposition of soil organic matter coupled with further ammonification and nitrification and there were available to cotton. Similar record of availability of nitrogen was earlier mentioned by Prakash et al. (2002) ${ }^{[7]}$.

\section{Biological properties of soil}

Application of recommended dose of Nutrient through organics on $\mathrm{P}$ equivalent basis FYM @ 12.5t ha ${ }^{-1}$ observed the highest population of bacteria and fungi and near about equal colonies were found in ST + PPFM @1\% at FL \& BD+ NC + Intercrop with blackgram BGS and seed treatment of bio- fertilizer + foliar application of PPFM @ 1 $\%$ at FL \& BD $\left(\mathrm{T}_{3}\right)$ and ST + PPFM @ $1 \%$ at FL \& BD + cotton + sunhemp (GMS). The similar trend of observations was noted during 2016-17 and 2017-18 at both the stages. However, in case of actinomycetes population was more in combined application of ST+ PPFM @1\% at FL \& BD+ NC + cotton+ sunhemp (GMS) (1:1) than ST + PPFM @1 \% at FL \& BD+ NC + Intercrop with blackgram BGS (1:1) and ST+ PPFM @1\% at FL \& BD+ NC + cotton+ sunhemp (GMS) at flowering and boll bursting stage was obtained first and second year of experimentation.

Table 3: Microbial population in soil at 50\% flowering and 50\% bursting stage as influenced different organic sources of manures

\begin{tabular}{|c|c|c|c|c|c|c|c|}
\hline & \multirow{2}{*}{ Treatments } & \multicolumn{2}{|c|}{\begin{tabular}{|c|}
$\begin{array}{c}\text { Bacterial population } \\
\left(\mathrm{cfu} \times 10^{-6} \mathrm{~g}^{-1} \text { soil }\right)\end{array}$ \\
\end{tabular}} & \multicolumn{2}{|c|}{$\begin{array}{l}\text { Fungal population } \\
\left(\mathrm{cfu} \times 10^{-4} \mathrm{~g}^{-1} \text { soil }\right)\end{array}$} & \multicolumn{2}{|c|}{$\begin{array}{c}\text { Actinomycetes population } \\
\left(\mathrm{cfu} \times 10^{-4} \mathrm{~g}^{-1} \text { soil }\right)\end{array}$} \\
\hline & & \begin{tabular}{|c|} 
At 50\% \\
flowering
\end{tabular} & $\begin{array}{c}\text { At 50\% boll } \\
\text { bursting }\end{array}$ & $\begin{array}{c}\text { At 50\% } \\
\text { flowering }\end{array}$ & $\begin{array}{c}\text { At 50\% boll } \\
\text { bursting }\end{array}$ & $\begin{array}{c}\text { At 50\% } \\
\text { flowering }\end{array}$ & $\begin{array}{l}\text { At 50\% boll } \\
\text { bursting }\end{array}$ \\
\hline $\mathrm{T}_{1}$ & Absolute control (no organic/ Inorganics) & 11.0 & 6.2 & 12.4 & 5.1 & 1.9 & 1.3 \\
\hline$T_{2}$ & RD of Nutrient through organics on P equivalent basis (FYM @ $12.5 \mathrm{t} \mathrm{ha}^{-1}$ ) & 36.0 & 23.4 & 16.3 & 10.6 & 2.7 & 1.8 \\
\hline $\mathrm{T}_{3}$ & Seed treatment of bio- fertilizer + foliar application of PPFM @ $1 \%$ at FL \& BD & 24.0 & 15.6 & 14.5 & 9.4 & 8.0 & 5.2 \\
\hline $\mathrm{T}_{4}$ & Neem cake $(\mathrm{NC}) @ 250 \mathrm{kgha}^{-1}$ & 17.7 & 11.5 & 13.5 & 8.8 & 6.3 & 4.1 \\
\hline $\mathrm{T}_{5}$ & GM of sunhemp (GMS) in between cotton rows (1:1) & 21.0 & 15.0 & 14.7 & 9.6 & 7.3 & 4.7 \\
\hline $\mathrm{T}_{6}$ & Intercrop with black gram BGS $(1: 1)$ & 19.0 & 12.4 & 13.2 & 8.6 & 9.0 & 5.9 \\
\hline $\mathrm{T}_{7}$ & ST + PPFM @ $1 \%$ at FL \& BD+ NC & 16.0 & 10.4 & 15.4 & 10.0 & 6.7 & 4.4 \\
\hline $\mathrm{T}_{8}$ & ST + PPFM @ $1 \%$ at FL \& BD + cotton+ sunhemp (GMS) (1:1) & 28.2 & 18.3 & 15.9 & 10.3 & 9.7 & 6.3 \\
\hline $\mathrm{T}_{9}$ & ST+ PPFM @ $1 \%$ at FL \& BD+ NC + cotton+ sunhemp (GMS) (1:1) & 23.0 & 13.7 & 14.3 & 9.3 & 11.0 & 7.1 \\
\hline$T_{10}$ & ST + PPFM @ $1 \%$ at FL \& BD+ NC + Intercrop with black gram BGS (1:1) & 31.0 & 20.2 & 15.5 & 10.1 & 12.0 & 7.0 \\
\hline
\end{tabular}

\section{Conclusion}

The soil physical, chemical and biological properties were improved with FYM @ $12.5 \mathrm{t} \mathrm{ha}^{-1}$ ha followed by seed treatment of biofertilzer +PPFM PGR spray@1\% + neem cake @ $250 \mathrm{~kg} \mathrm{ha}^{-1}$ with cotton + sunhemp GMS (1:1).

\section{References}

1. Annynmous. Textile Exchange -Organic Cotton Market Report Anonymous. Annual Report, All India Coordinated Research Report, CICR, Coimbatore 2018.

2. Chalwade PB, Kulkarni VK, Lakade MB. Effect of inorganic and organic fertilization on physical properties of Vertisol J Soil and crops 2006;16(1):148-152.

3. Ghuman BS, Suri HS. Effect of manuring on soil properties and yield of rainfed wheat. J Indian Soc. Soil Sci 2006;54(1):6-11.

4. Gupta MK, Sharma SD. Effect of tree plantation on soil properties, profile morphology and productivity index: Popular in Yamunanagar District of Hariyana. Annals of Forestry 2009;17(1):43-70.

5. Halemani HL, Hallikeri SS, Nooli SS, Nandagavi RA, Harish Kumar HS. Effect of organics on cotton productivity and physicochemical properties of soil. In: International symposium on Strategies for sustainable cotton production-A global vision. 2 . Crop production, 23-25, VAS, Dharwad 2004, 174-180.
6. Olsen SR, Cole CV, Watanable FS, Dean LA. Estimation of available phosphorus in soils by extraction with sodium carbonate. US Dept. Agriculture. Circular No. 1954, 939.

7. Prakash YS, Bhandoria PBS, Rakshit A. Comparative efficacy of organic manures on the changes in soil properties and nutrient availability in an Alfisol. J Indian Soc. Soil Sci 2002;50(2):219221.

8. Rao S, Janwade AD. Influence of integrated nutrient management practices on physico-chemical properties of cotton growing soils. J Cotton Res. Dev 2009;23(1):60-63.

9. Ravindra Kumar, Turkhede AB, Meena Shrimohan, Nagar RK. Performance of American cotton-legumes based intercropping system on nutrient uptake and soil nutrient status Agric. Sci. Digest 2016;36(3):234-236.

10. Venkatashwarlu B. Role of bio-fertilizers in organic farming: Organic farming in rainfed agriculture Central institute for dry land agriculture, Hyderabad 2008, 85-95.

11. Walkley AJ, Black CA. Estimation of soil organic carbon by the chronic acid titration method Soil Science 1934;37:29-38.

12. Wollum AG. In: Methods of Soil Analysis, Part II, Chemical and Microbiological Methods by Page AL, RH Miller and DR Keeney (eds.), Agronomy Monograph No. 9 (2nd edition) American Society of Agronomy and Soil Science Society of America, Madison, Wisconsin, USA 1982, 781-794. 